health of a student, the indirect approach is the most suitable, although a counselling psychological service is advised for the universities of countries which have suffered most from the War. The report also contains sections setting out the Association's views on the provision of some form of health instruction, the inspection of the student's environment, the treatment of minor ailments of the sick student and the treatment of students who are seriously ill.

\section{Pests of Ornamental Plants}

The late G. Fox Wilson performed a great service to horticulture in his studies of insect and other pests which attack flowers and shrubs, and a compendium of these studies was first published by the Ministry of Agriculture and Fisheries in 1937. This has long been out of print, so that a second edition, enlarged and modernized, is very welcome (Bulletin No. 97, Pests of Flowers and Shrubs; 105 pp. +117 pl.; London : H.M. Stationery Office, $1950 ; 4 s .6 d$. net). A short general introduction is followed by fairly detailed consideration of measures of control. The more ubiquitous pests such as slugs, millepedes, aphids, wireworms and leatherjackets are described in a general section, and thereafter localized pests on lawns, borders, bulbs and corms, rock gardens and glasshouses receive consideration. Such a horticultural arrangement necessitates a more adequate index than is provided, for it is not always easy to make rapid reference to a particular pest. This slight criticism must not, however, be allowed to detract from the value of the bulletin, which is a sound book of reference, thoroughly informative and very well illustrated. It should appeal to the gardener and equally to the advisory officer. One useful feature is that the results of future work with modern sprays, like HETP and TEPP, or modern soil treatments like benzene hexachloride, will be readily applicable to the text, for control measures have been considered as principles rather than mere specific remedies.

\section{St. Andrews Mathematical Colloquium, 1951}

MANY mathematicians will remember with pleasure the colloquia held at the University of St. Andrews under the sponsorship of the Edinburgh Mathematical Society in 1926, 1930, 1934 and 1938. It was intended to hold such meetings every four years, but the War and the difficult post-war conditions made this impossible until now. The fifth St. Andrews Colloquium took place during July 18-28, and proved even more successful than its predecessors. There were 110 people present at University Hall, St. Andrews, including overseas representatives from Australia, Belgium, Canada, Egypt, Eire, Holland, India, Switzerland and the United States. The inaugural address was given by Prof. H. W. Turnbull, who gave an account of the fascinating historical researches arising from the preparation for publication by the Royal Society of the letters of Isaac Newton. There were five sets of formal lectures: (1) Prof. H. S. M. Coxeter (Toronto) on kaleidoscopes and quadratic forms; (2) Prof. A. Erdélyi (Pasadena, California) on the analytic theory of systems of partial differential equations ; (3) Mr. A. E. Ingham (Cambridge) on the analytic theory of numbers; (4) Prof. J. L. Synge (Dublin) on the geometry of function-space and its applications to mathematical physics ; (5) Prof. G. Temple (London) on mathematical problems of supersonic aerodynamics. In addition, single lectures were given by Prof. Sophie Piccard (Neuchâtel) on the theory of groups and by
Prof. L. E. J. Brouwer (Amsterdam) on the influence of mathematics on logic. At the concluding meeting, Prof. Temple expressed the thanks of all present to those responsible for the successful organization of the colloquium, in particular to Dr. D. E. Rutherford (St. Andrews). It is hoped that the sixth St. Andrews Colloquium will be held during 1955.

\section{Society of Dairy Technology}

THE Council of the Society of Dairy Technology has established a medal, to be known as the Society of Dairy Technology Gold Medal, which will be awarded to anyone from any part of the world who, in the view of the Council, has rendered particularly distinguished service to the industry. The award will be made not more than three times in ten years. The first award, to be presented at the Society's annual general meeting in London on October 22, is being made to Dr. Richard Seligman, who has been responsible for many developments of outstanding and world-wide importance in the dairy industry.

The Council of the Society has elected Mr. James Mackintosh, lately principal livestock husbandry officer, South-Eastern Provinces, National Agricultural Advisory Service, and formerly head of the Dairy Husbandry Department of the National Institute for Research in Dairying, and Mr. E. B. Anderson, lately chief chemist of United Dairies, Ltd., to be honorary members of the Society of Dairy Technology, in recognition of their services to the dairy industry and to the Society.

\section{Announcements}

Applications are invited for the Gabriella Zuccar research grant of 250,000 lire for work at the Zoological Station of Naples for at least six months during 1952. The grant may be renowed for a maximum of three years. Applications, including an outline of the proposed investigation, should reach the Rector, University of Padua, by October 31.

The twenty-sixth annual conference of Aslib will be held at Ashorne Hill, near Leamington Spa, during October 5-8. The programme will include such subjects as the training and organization of staff, including voluntary workers and students; what can be learnt from industrial efficiency methods, such as job analysis, time and motion study, etc.; and practical bibliographical and documentary projects in operation in the international field, with special reference to the part of Unesco in them. Opportunities will be provided for groups to discuss subjects in their particular field of interest. Further details can be obtained from Aslib at 4 Palace Gate, London, W.8.

The United Nations Department of Public Information has now issued a 36-page pamphlet, "World Facts and Figures" (New York: United Nations; London: H.M. Stationery Office, 1951. 25 cents; 1s. 9d.), giving some cogent facts about population, production, including coal and petroleum, electrical energy, steel, strategic metals, cement, rubber, sulphuric acid, transport and communications, medical facilities and newspapers. These are taken from second editions of the "United Nations Statistical Year Book" and "Demographic Yearbook". The facts included are sufficiently comprehensive for the pamphlet to provide the ordinary man or woman with a convenient means of keeping some current discussions on a factual basis. 